\title{
Awareness and Practice on Household Solid Waste Management among the Community People
}

\author{
Sharmin Sultana1 ${ }^{*}$, Md. Shariful Islam², Ferdous Jahan ${ }^{3}$, Fahima Khatun ${ }^{4}$ \\ ${ }^{1}$ MSN, Community Health Nursing, NIANER, Dhaka, Bangladesh \\ ${ }^{2}$ Faculty of Adult and Elderly Health Nursing, NIANER, Dhaka, Bangladesh \\ ${ }^{3}$ Faculty of Community Health Nursing, NIANER, Dhaka, Bangladesh \\ ${ }^{4}$ Faculty of Women's Health Nursing, National Institute of Advanced Nursing Education \& Research, Dhaka, Bangladesh \\ Email: *sharmin.minu1984@gmail.com
}

How to cite this paper: Sultana, S., Islam, Md.S., Jahan, F. and Khatun, F. (2021) Awareness and Practice on Household Solid Waste Management among the Community People. Open Journal of Nursing, 11, 349-366. https://doi.org/10.4236/ojn.2021.115031

Received: March 21, 2021

Accepted: May 23, 2021

Published: May 26, 2021

Copyright () 2021 by author(s) and Scientific Research Publishing Inc. This work is licensed under the Creative Commons Attribution International License (CC BY 4.0).

http://creativecommons.org/licenses/by/4.0/ (c) (i) Open Access

\begin{abstract}
Household solid waste management is a major public health concern in the community people and closely related to daily human life. Community people can play a pivotal role in managing household solid waste. Objectives: This study was aimed to assess the awareness and practice of household solid waste management among the people living in the Mugda community in Dhaka. Methods: A descriptive co-relational study design was used. A total of 112 participants were selected with the convenience sampling technique. The data collection period was from July 2019 to June 2020. The data were collected from the participants by face-to-face interview through the door-to-door survey by using a structured questionnaire. Data were analyzed by using descriptive, Pearson correlation, t-test, and one-way ANOVA statistics. Results: Finding of the study shows that the mean awareness regarding household solid waste management was $7.96(\mathrm{SD}=1.64)$ and the mean practice was 2.94 (SD $=1.35$ ) respectively. It indicates that the awareness and practice of community people were at a moderate level. In bivariate analysis, it has been shown that training on household solid waste management ("P $<0.001$ "), and recyclable waste $(\mathrm{p}=0.019)$ were statistically significantly correlated with household solid waste management practice. Conclusion: Overall awareness and practice level of household solid waste management were at a moderate level among the community people. Training on household solid waste management and recyclable waste management were statistically significantly correlated with household solid waste management. Policymakers can use this baseline data to make a strategy for increasing awareness among the community people.
\end{abstract}




\section{Keywords}

Awareness, Practice, Solid Waste Management, Community People

\section{Introduction}

Household solid waste management is a major public health concern among the community people throughout the world and closely related to daily human life [1]. Household solid waste management means the collection, transport, processing, recycling, disposal, and monitoring of waste materials [2]. Bangladesh is one of the most polluted countries in the world due to its improper household solid waste management [3]. Household solid waste management is a great challenge to the people living in the community. Daily solid waste generates in Bangladesh was estimated to be 8280 tons and annually generate 3.02 million tons. Approximately $63 \%$ of people didn't manage household solid waste properly [3]. However, about $39 \%$ of people didn't manage household solid waste properly in the world [4]. In India, it was estimated that people of the municipal area generated household solid waste daily at 160,000 MT (Metric Ton) [5].

Household solid waste (HSW) has both direct and indirect effects on the environment and human welfare [6]. Improper household solid waste management causes serious health effects in daily life. Poor waste management, inadequate collection, and improper disposal of the waste facility could lead to various diseases, infections, and infestation. These include Malaria, Typhoid, Diarrhea, Cholera, Helminthiasis, and Dysentery [5]. Poor management of household solid waste destroys the natural beauty; damage the landscape, fire hazards, foul smells, unpleasantness, additional dredging costs of waterways, silting up of reservoirs, and decrease in plant productivity, deterioration of structures and structural foundations, and depreciation of land value [7]. A clean environment influences good health and improves the quality of human life. Lack of good and enough infrastructures, insufficient coverage of collection system, inadequate awareness, and less involvement of the household key stakeholder are the main reasons for improper household solid waste management in the community [5]. Awareness of various aspects of waste management can help to reduce waste generation and improve the waste management process [8].

Awareness and practice can prevent household solid waste management problems. A prior study revealed that the majority of the people (53\%) living in a community in Bangladesh are unaware to manage the household solid waste properly [9]. However, in Pakistan, $28 \%$ of the community people are not aware to manage household solid waste [4]. Approximately $41 \%$ of community people in Malaysia had inadequate awareness regarding household solid waste management [10]. A previous study reported that above $50 \%$ of the people do not use the dustbin, and most of them threw waste outside in the home or open fields in a public place. However, the majority of the people used open contain- 
ers and plastic waste. In contrast, most of the people in Pakistan do not use dustbins, and most of them used open containers with plastic waste, which is being recycled into total plastic waste [4].

In previous literature, it was revealed that the majority of the community people did not have an idea or inadequate knowledge regarding household solid waste management and have a negative attitude towards waste management in their homes [8]. Awareness and practices can be improved by providing proper knowledge regarding household solid waste management. Waste management education and awareness strategy, mass media, radio, television as well as social media can play a significant role in the improvement of awareness and practice regarding household solid waste management [11]. There is a huge gap between awareness and household solid waste management practice among the community people. In the Philippines, most of the community people were aware of household solid waste management, but their practice level was poor [7]. The existing literature found a negative relationship between awareness and practice regarding household solid waste management. In Pakistan, most of the community people are aware to manage household solid waste but few people did proper practice to manage waste [8].

This study finding would contribute to developing an awareness-building program regarding household solid waste management to increase the awareness and practice level among the community people.

This finding also acts as a baseline data for further study at identifying factors related to household solid waste management, and policymakers can use this data to make a strategy for increasing awareness and practice.

In Bangladesh, there is a dearth of the study conducted on awareness to improve household solid waste management practice among the community people.

A previous study highlighted only the factors related to household solid waste management. The current study focuses on awareness and practice regarding household solid waste management. Therefore, it is necessary to conduct a study entitled awareness and practice on household solid waste management among the people living in a community of Bangladesh.

\section{Objectives}

\section{1) General Objective:}

To assess the awareness and practice on household solid waste management among the community people.

2) Specific Objectives:

a) To describe the socio-demographic characteristics of the community people.

b) To assess the level of awareness on household waste management among the community people.

c) To identify the level of household waste management practice among the community people.

d) To examine the relationship between awareness and practice on household solid waste management among the community people. 


\section{Methodology}

\subsection{Study Design}

Descriptive co-relational study design was used to assess the awareness and practice of household solid waste management among the community people. The study was conducted from July 2019 to June 2020 .

\subsection{Study Participants}

All the people living in the Mugda community in Dhaka were invited to participate in this study. Mugda is situated in Dhaka South City Corporation, Zone-2, and Ward 6 under Mugda Thana. This community is divided into two areas: South Mugda and North Mugda. According to city corporation zonal office data, there are 1600 house in this community where 5000 families are living among them male 45,500, female-37,228. Mugda is a densely populated area and the level of people's education is poor. The sample size was estimated by $\mathrm{G}$ power analysis in which accepted significant level $(\alpha)$ 0.05, an expected power 0.80 (1- $\beta$ ) and effect size 0.3 . The actual sample size was 84 . To reduce the attrition rate, $20 \%$ more samples were added. Therefore, the total sample of this study was 112 . The community people who met the following inclusion criteria were included in this study, Age from 18 years old and above, both male \& female who are living in Mugda Community at least one year, conscious, mentally alert and able to co-operate and willingly participate in this study.

\subsection{Instruments}

A total of 37 items structured questionnaire was used to assess the awareness and practice of household solid waste management. This questionnaire was developed by the researcher based on a literature review. This instrument was divided into three parts including 1) Socio-demographic questionnaire; 2) Awareness of household solid waste management questionnaires; 3) Practice of household solid waste management questionnaires.

Socio-demographic questionnaire: An 11-item socio-demographic questionnaire was used to measure the characteristics of the community people. This section includes age, gender, education, family, income, occupation, marital status, waste composition, and household waste problem.

\section{Awareness of Household Solid Waste Management Questionnaire:}

A 12-item Awareness of Household Solid Waste Management Questionnaire with a yes/no/don't know option was used to assess the awareness level of household solid waste management among the community people. The questionnaire was developed by the investigator based on a literature review. The score was ranged from 0 to 12 . Each correct answer receives 1 point while an incorrect answer receives zero points. Awareness was categorized into three levels: low, moderate, and high. A high score indicates a high level of awareness regarding household solid waste management.

The practice of Household Solid Waste Management Questionnaire: A 
14-item Practice of Household Solid Waste Management Questionnaire was used to measure the community people's practice level which was developed by the researcher based on a literature review. The people were asked to rate their opinion using a 5-point likert scale ranging from $1=$ Never to $5=$ always. The score was ranged from 14 to 70 and converted into a percentage. A high score indicates a high level of practice.

\subsection{Data Collection Methods}

The data collection was carried out by the principal investigator. Data were collected after obtaining approval from the Institutional Review Board (IRB) (IRB NO. NIA-S-2019-75) at the National Institute of Advanced Nursing Education and Research (NIANER) and Bangabandhu Sheikh Mujib Medical University (BSMMU), Dhaka Bangladesh. Then permission was received from the Counselor of the selected community in Dhaka. The researcher highly considered the human right of the participants of this study. The researcher explained the procedure and benefit of the study to the selected participants. The anonymity and confidentiality of the participants was strictly maintained. Data were collected from December 2019 to January 2020. A written/thumbprint informed consent paper was obtained from the participants. Participants were informed that they could withdraw their participation at any time without any penalty. The data were collected from the participants by face to face interview through the door to door survey.

\subsection{Data Analysis}

After completion of data collection, data were checked and manage for consistency to minimize error. The collected data were analyzed using a computer software program (SPSS version 21). Descriptive statistics such as frequency, percentage, mean, and SD were used to measure the variables. Inferential statistics such as independent t-test, one-way ANOVA, and Pearson correlation test were used to examine the relationship between awareness and practice. Results were evaluated using $95 \%$ confidence intervals and the level of significance was set at $\mathrm{p}<0.05$.

\section{Results}

This chapter presents the results of the major variables. These include 1) socio-demographic characteristics of the participants, 2) awareness level on household solid waste management, 3) level of practice on household solid waste management, and 4) relationship between awareness and practice on household solid waste management among the community people. Total sample size was 112. The findings are described in detail below.

\subsection{Demographic Characteristics of the Participants}

Table 1 shows socio-demographic characteristics of the community people at 
Mugda in Dhaka. According to findings, the mean age was 32.25 ( SD = 10.87) years; this was ranged from 18 to 60 years. Most of the participants $(79.46 \%)$

Table 1. Distribution of socio-demographic characteristics of the participant $(\mathrm{N}=112)$.

\begin{tabular}{|c|c|c|c|c|}
\hline Variable & Category & $\mathbf{N}$ & $(\%)$ & $\mathrm{M} \pm \mathrm{SD}$ \\
\hline Age & & & & $32.25 \pm 10.871$ \\
\hline \multirow{2}{*}{ Gender } & Male & 23 & 20.53 & \\
\hline & Female & 89 & 79.46 & \\
\hline \multirow{2}{*}{ Religion } & Islam & 110 & 98.21 & \\
\hline & Hindu & 02 & 1.78 & \\
\hline \multirow{4}{*}{ Marital Status } & Married & 100 & 89.28 & \\
\hline & Unmarried & 08 & 7.14 & \\
\hline & Widowed & 01 & 0.89 & \\
\hline & Divorced & 03 & 2.67 & \\
\hline \multirow{5}{*}{ Education } & No education & 54 & 48.21 & \\
\hline & Primary & 32 & 28.57 & \\
\hline & Secondary & 22 & 19.64 & \\
\hline & HSC & 03 & 2.67 & \\
\hline & More than HSC & 01 & 0.9 & \\
\hline \multirow{5}{*}{ Occupation } & Govt. job & 01 & 0.9 & \\
\hline & Private job & 03 & 2.67 & \\
\hline & House wife & 24 & 21.42 & \\
\hline & Business & 64 & 57.14 & \\
\hline & Self Service & 20 & 17.85 & \\
\hline Monthly Family Income & \multicolumn{2}{|c|}{ Mini-3000, Max-22,000 } & & $11,955.36 \pm 5278.528$ \\
\hline \multirow{2}{*}{ Residential Status } & Own & 7 & 6.25 & \\
\hline & Rented & 105 & 93.75 & \\
\hline \multirow{3}{*}{ Types of Solid waste } & Recyclable waste & 09 & 8.03 & \\
\hline & Non-recyclable waste & 80 & 71.42 & \\
\hline & Others & 23 & 20.53 & \\
\hline \multirow{2}{*}{$\begin{array}{l}\text { There is no good System for } \\
\text { disposal of waste }\end{array}$} & Yes & 75 & 66.96 & \\
\hline & No & 37 & 33.03 & \\
\hline \multirow{2}{*}{ Cost is high } & Yes & 75 & 66.96 & \\
\hline & No & 37 & 33.00 & \\
\hline \multirow{2}{*}{ Irregular Service } & Yes & 58 & 51.78 & \\
\hline & No & 54 & 48.21 & \\
\hline Lack of Container to collect & Yes & 40 & 35.71 & \\
\hline waste at home & No & 72 & 64.28 & \\
\hline Others & Yes & 36 & 32.14 & \\
\hline $\begin{array}{l}\text { Have you any training on } \\
\text { household solid waste }\end{array}$ & Yes & 21 & 18.75 & \\
\hline management? & No & 91 & 81.25 & \\
\hline
\end{tabular}


were female and the majority of them (98.21\%) were Muslims. Most of the participants $(89.28 \%)$ were married. Nearly half $(48.21 \%)$ of the participants had no education and above half of (57.14\%) of the participants were a businessman. The mean monthly family income was $11,955.36(\mathrm{SD}=5278.528 \mathrm{BDT})$. The majority of (93.75\%) the respondents were living in a rented house. Most of the participants (66.96\%) had a poor system for disposal of waste and the cost is high. However, more than half of the participants (51.78\%) had irregular service. One-third of participants had a lack of containers to collect waste at home and most of them $(81.25 \%)$ had received no training on household solid waste management.

\subsection{Awareness Level on Household Solid Waste Management of the Community People}

Table 2 shows the distribution of frequency, percentages, means, and SD of awareness level of the community people on solid household waste management. According to findings, the mean score of awareness of the participants about household solid waste management was calculated as $7.96(\mathrm{SD}=0.64)$ out of a maximum of 12 points which indicates a moderate level of awareness. It reveals that the majority (78.8\%) of the people had a low to moderate level of awareness. While the least number of people (15.2\%) had a high level of awareness. Based on item analysis, results reflected that the majority of the participants had correct answer regarding 1) respiratory distress, diarrhea, and many other diseases arise due to improper waste management $(96.42 \%), 2)$ all streets should be

Table 2. Distribution of awareness level on household waste management among the participants $(\mathrm{N}=112)$.

\begin{tabular}{|c|c|c|c|c|c|}
\hline \multirow{2}{*}{ Variable } & \multicolumn{2}{|c|}{ Correct } & \multicolumn{2}{|c|}{ Incorrect } & \multirow{2}{*}{$\mathrm{M} \pm \mathrm{SD}$} \\
\hline & $\mathrm{N}$ & $\%$ & $\mathrm{~N}$ & $\%$ & \\
\hline Household solid waste management committee are needed in the community. & 88 & 78.57 & 24 & 21.42 & $0.79 \pm 0.412$ \\
\hline Every people have to know about household solid waste management. & 80 & 71.42 & 32 & 28.57 & $0.71 \pm 0.454$ \\
\hline Local authorities have no role to play in the house hold solid waste management. & 42 & 37.50 & 70 & 62.80 & $0.38 \pm 0.486$ \\
\hline $\begin{array}{l}\text { Respiratory distress, diarrhea and many other diseases arise due to improper waste } \\
\text { management. }\end{array}$ & 108 & 96.42 & 4 & 3.57 & $0.96 \pm 0.186$ \\
\hline Household solid waste can't reuse or recycle. & 73 & 65.17 & 39 & 34.82 & $0.65 \pm 0.479$ \\
\hline Everybody awarded of electronic household solid waste management. & 43 & 38.39 & 69 & 61.60 & $0.38 \pm 0.489$ \\
\hline Waste disposal on open places will be harmful for human health. & 104 & 92.85 & 8 & 7.14 & $0.93 \pm 0.259$ \\
\hline $\begin{array}{l}\text { Community people are awarded of any legislation which governs household solid waste } \\
\text { management. }\end{array}$ & 22 & 19.64 & 90 & 80.35 & $0.20 \pm 0.399$ \\
\hline All streets should be clean and free of waste. & 106 & 94.64 & 6 & 5.35 & $0.95 \pm 0.226$ \\
\hline Incineration is the effective disposal mechanism for household solid waste management. & 45 & 40.17 & 67 & 59.82 & $0.40 \pm 0.492$ \\
\hline Delay in household solid waste disposal causes of many difficulties. & 94 & 83.92 & 18 & 16.07 & $0.84 \pm 0.369$ \\
\hline I am always concern about collect and dispose of household solid waste management. & 87 & 77.67 & 25 & 22.32 & $0.78 \pm 0.418$ \\
\hline
\end{tabular}

Total mean $=7.96(\mathrm{SD}=1.64)$. 
cleaned and free of waste $(94.64 \%), 3)$ waste disposal on open places will be harmful to human health $(92.85 \%), 4)$ delay in household solid waste disposal causes of many difficulties $(83.92 \%), 5$ ) household solid waste management committee are needed in the community (78.57\%), 6) I am always concern about collect and dispose of household solid waste management (77.67\%), and 7) every people have to know about household solid waste management (71.42\%). In contrast, most of the community people had incorrect awareness regarding 1) community people are awarded of any legislation which governs household solid waste management $(80.3 \%), 2)$ local authorities have no role to play in the household solid waste management $(62.80 \%), 3)$ everybody awarded of electronic household solid waste management (61.60\%), and 4) incineration is the effective disposal mechanism for household solid waste management (59.82\%).

\subsection{Practice Level on Household Solid Waste Management of the Community People}

According to Table 3, it shows the distribution of participant's level of practice on household solid waste management of the community people. According to findings, the mean practice score of household solid waste management was found as $2.94(\mathrm{SD}=1.35)$ out of a maximum of 5 points which indicates a moderate level of practice. Around $99 \%$ of people had a low to moderate level of practice. The majority of the respondents (95\%) never used kitchen waste compostin gardening. Most of them (92\%) participants did never burn solid waste when

Table 3. Distribution of participants household solid waste management practice $(\mathrm{N}=112)$.

\begin{tabular}{|c|c|c|c|c|c|c|}
\hline Variable & $\begin{array}{l}\text { Never } \\
\mathrm{n}(\%)\end{array}$ & $\begin{array}{c}\text { Seldom } \\
\text { n (\%) }\end{array}$ & $\begin{array}{c}\text { Sometime } \\
\text { n (\%) }\end{array}$ & $\begin{array}{l}\text { Often } \\
\text { n (\%) }\end{array}$ & $\begin{array}{l}\text { Always } \\
\text { n (\%) }\end{array}$ & $\mathrm{M}(\mathrm{SD})$ \\
\hline I use different bins for waste disposal. & $75(66.96)$ & $7(6.25)$ & $11(9.82)$ & $2(1.78)$ & $17(15.17)$ & $1.92 \pm 1.490$ \\
\hline I throw waste to drain. & $48(42.85)$ & $30(26.78)$ & $15(13.39)$ & $7(6.25)$ & $12(10.71)$ & $2.15 \pm 1.330$ \\
\hline I use our kitchen waste as compost to me for Gardening. & $107(95.53)$ & $1(0.89)$ & $2(1.78)$ & $1(0.89)$ & $1(0.89)$ & $1.11 \pm .543$ \\
\hline I reuse grocery bags. & $13(11.60)$ & $4(3.57)$ & $25(22.32)$ & $21(18.75)$ & $49(43.75)$ & $3.79 \pm 1.350$ \\
\hline I reuse our old materials than buying a new one. & $13(11.60)$ & $1(0.89)$ & $21(18.75)$ & $28(25.00)$ & $49(43.75)$ & $3.88 \pm 1.307$ \\
\hline I throw waste to open dump. & $62(55.37)$ & $4(3.57)$ & $11(9.82)$ & $6(5.35)$ & $29(25.89)$ & $2.43 \pm 1.744$ \\
\hline I throw waste to open field. & $98(87.50)$ & $2(1.78)$ & $4(3.57)$ & $1(0.89)$ & $7(6.25)$ & $1.37 \pm 1.057$ \\
\hline I collect the waste in a household container without cover. & $6(5.35)$ & $3(2.67)$ & $1(0.89)$ & 00 & $102(91.07)$ & $4.69 \pm 1.023$ \\
\hline I collect the waste in plastic bag. & $4(3.57)$ & $1(0.89)$ & $6(5.35)$ & $4(3.57)$ & $97(86.60)$ & $4.69 \pm .901$ \\
\hline $\begin{array}{l}\text { I segregate bio-degradable and non-biodegradable wastes } \\
\text { at home. }\end{array}$ & $47(41.96)$ & $18(16.07)$ & $36(32.14)$ & $1(0.89)$ & $10(8.92)$ & $2.19 \pm .901$ \\
\hline I keep all the garbage in one garbage container. & $7(6.25)$ & $1(0.89)$ & $1(0.89)$ & $2(1.78)$ & $101(90.17)$ & $4.69 \pm 1.023$ \\
\hline $\begin{array}{l}\text { I use to burn the solid waste when I have bulk amount of } \\
\text { solid waste. }\end{array}$ & $104(92.85)$ & $3(2.67)$ & 00 & $1(0.89)$ & $4(3.57)$ & $1.20 \pm .804$ \\
\hline I dispose the solid waste regularly. & $10(8.92)$ & $5(4.46)$ & $16(14.28)$ & $21(18.75)$ & $60(53.57)$ & $4.04 \pm 1.29$ \\
\hline I dispose solid waste to waste collector. & $53(47.32)$ & 00 & $2(1.78)$ & $1(0.89)$ & $56(50.00)$ & $3.04 \pm 1.983$ \\
\hline
\end{tabular}

Total mean $=2.94(\mathrm{SD}=1.35)$. 
bulk. However, a large number of (91\%) participants always collect waste without a container, and most of them (90\%) always used one garbage container. Many respondents (87\%) never throw waste in the open field and the majority $(86 \%)$ of them always collect waste in a plastic bag. Above half (66\%) of the participants did never use different bins for waste disposal and more than half (55\%) of them never thrown waste to an open dump. In contrast above half (53\%) of the participants always disposed of solid waste to waste collectors and less than half (43\%) of them reused old materials.

\subsection{Relationship between the Socio Demographic Characteristics and Practice on Household Solid Waste Management among the Community People}

Table 4 showed the relationship between demographic characteristics and practice on household solid waste management. Bivariate analysis was done to examine

Table 4. Relationship between socio-demographic characteristics and practice of household solid waste management among the people $(\mathrm{N}=112)$.

\begin{tabular}{|c|c|c|c|c|c|}
\hline Variables & Category & $\mathbf{N}$ & $\mathrm{M} \pm \mathrm{SD}$ & $t / r / F$ & $\mathbf{P}$ \\
\hline \multirow{2}{*}{ Age } & $<32$ years & 66 & $2.48 \pm 1.32$ & \multirow{2}{*}{-0.129} & \multirow{2}{*}{0.898} \\
\hline & $>32$ years & 46 & $2.51 \pm 1.40$ & & \\
\hline \multirow{2}{*}{ Gender } & Male & 23 & $2.30 \pm 1.05$ & \multirow{2}{*}{-0.742} & \multirow{2}{*}{0.460} \\
\hline & Female & 89 & $2.54 \pm 1.41$ & & \\
\hline \multirow{2}{*}{ Religion } & Muslim & 110 & $2.50 \pm 1.35$ & \multirow{2}{*}{0.517} & \multirow{2}{*}{0.606} \\
\hline & Hindu and others & 02 & $2.00 \pm 1.41$ & & \\
\hline \multirow{2}{*}{ Marital status } & Married & 100 & $2.49 \pm 1.31$ & \multirow{2}{*}{-0.137} & \multirow{2}{*}{0.892} \\
\hline & Unmarried & 12 & $2.54 \pm 1.67$ & & \\
\hline \multirow{3}{*}{ Education } & No Education & 54 & $2.36 \pm 1.24$ & \multirow{3}{*}{2.705} & \multirow{3}{*}{0.071} \\
\hline & Primary & 32 & $2.28 \pm 1.30$ & & \\
\hline & SSC and above & 26 & $3.02 \pm 1.52$ & & \\
\hline \multirow{3}{*}{ Occupation } & Job & 28 & $2.24 \pm 1.22$ & \multirow{3}{*}{0.887} & \multirow{3}{*}{0.415} \\
\hline & Businessman & 64 & $2.39 \pm 1.35$ & & \\
\hline & Others & 20 & $2.85 \pm 1.52$ & & \\
\hline \multirow{3}{*}{ Monthly Family income } & Low income & 46 & $2.47 \pm 1.43$ & \multirow{3}{*}{0.777} & \multirow{3}{*}{0.462} \\
\hline & Moderate income & 30 & $2.73 \pm 1.46$ & & \\
\hline & High income & 36 & $2.32 \pm 1.12$ & & \\
\hline \multirow{2}{*}{$\begin{array}{l}\text { Residential } \\
\text { Status }\end{array}$} & Owned & 07 & $2.93 \pm 0.450$ & \multirow{2}{*}{0.884} & \multirow{2}{*}{0.378} \\
\hline & Rented & 105 & $2.46 \pm 1.38$ & & \\
\hline \multirow{2}{*}{ Types of Solid waste } & Non-recyclable waste & 09 & $3.50 \pm 1.41$ & \multirow{2}{*}{2.386} & \multirow{2}{*}{0.019} \\
\hline & Recyclable waste & 103 & $2.40 \pm 1.31$ & & \\
\hline \multirow{2}{*}{$\begin{array}{l}\text { Training on household } \\
\text { solid waste management }\end{array}$} & Yes & 21 & $3.74 \pm 1.31$ & \multirow{2}{*}{5.219} & \multirow{2}{*}{0.000} \\
\hline & No & 91 & $2.20 \pm 1.19$ & & \\
\hline Total awareness & & & & -0.008 & 0.930 \\
\hline
\end{tabular}


the relationship between demographic characteristics and practice on household solid waste management. It was found that the participants who received training on household solid waste management were significantly correlated with practice $(t=5.219, \mathrm{P}<0.001)$. It means that people who received training on household waste management should good practice. Finding also found that solid waste composition was highly correlated with practice on household solid waste management $(t=2.386, p=0.019)$. It means that the people who did non-recyclable waste type of solid waste had better practice towards household solid waste management. The rest of the other variables were non-significant towards household solid waste management.

\section{Discussion}

The purpose of this study was to assess the awareness and practice of household solid waste management among the community people at Mugda in Dhaka. The finding shows that community people have a low to moderate level of awareness regarding household solid waste management. Discussions are held in following heading:

\subsection{Socio-Demographic Characteristics of the Participants}

The current study shows that the majority of the participants said types of solid waste were a non-recyclable waste because maximum solid wastes were unhygienic, unhealthier as well as source of different germ. The same result was found in the Nigeria study. In Nigeria, a study was conducted among the people to assess the awareness and practice of waste management. Findings revealed that most of the participants had a good awareness of recyclable waste. This might be due to similar education, cultural background, and environment between the two countries. In this study, majority of the participants had not received any formal training on household solid waste management. Inadequate training may impact awareness level meaning that lower the training on household solid waste management lower the awareness and practice to manage household solid waste. The same result was found in a previous study conducted by [2]. A previous study found that community awareness programs played an effective role to increase people practice level. Another study reported that the people who received formal training had better practice to manage household solid waste properly [8].

\subsection{Awareness Level of Household Solid Waste Management among the participants}

The present study found that community people had a low to moderate level of awareness. The finding of this study is similar to the previous study conducted by [4] in Pakistan and Philipines. In Pakistan, a descriptive cross sectional study was conducted to identify the level of awareness and practice regarding household solid waste. The finding showed that the majority of the participants had a 
moderate level of awareness. This result might be due to similar educational background, culture, income, and educational information on household solid waste management [4]. According to item analysis majority of the participants answered correctly toward the following items: 1) Respiratory distress; diarrhea and many other diseases arise due to improper waste management. 2) Streets should be clean and free of waste. 3) Waste disposal in open places will be harmful to human health. 4) Household Solid waste management committees are needed in the community. These results are nearly similar to other studies conducted in Malaysia, Pakistan, and Indonesia [4] [12] and [8] respectively. The reasons for the same results might be due to the similar demographic background of the respondents, culture and role of mass-media, billboard, electronic media and print media, which could provide information regarding the following items. Information was also received from a community health worker. The majority of the participants answered incorrectly toward the following items: 1) Local authorities have no role to play in the household solid waste management. 2) Community people are awarded of any legislation of household solid waste management. This result is not in accord with the Indonesian study. The Indonesia population are aware any legislation for waste management and contribution of local authority conducted by [13]. The strategy may be developed to enhance the awareness level of the incorrect items of the awareness questionnaire.

\subsection{Practice on Household Solid Waste Management among the Participants}

The finding of the present study showed that the participants had a low to moderate level of practice. The total mean score of household solid waste management practice was 2.94 . The finding showed that the majority of the participants never used kitchen waste as compost for gardening due to lack of knowledge about compost, and did not have available space for gardening. However, the present study results are inconsistent with a prior study conducted in Uganda. In Uganda, most of the study participants had adequate awareness of kitchen waste compost and gardening. That reason for their adequate awareness may be participants had education and available space for gardening [14]. The study also revealed that the majority of the participants were never used to burn when a bulk amount of solid waste. The reason for this result is that the participants had knowledge of burn is harmful to health and the environment. This finding is similar to the previous study conducted by [15]. Most of the participants always collected the waste in a household container without any cover. This is harmful to health and the environment, Participants had no better practice system for waste collection and not available bin with a lid. However, the results differ from other study conducted in Nigeria because participants had adequate knowledge of waste storage, better waste collection system, and available waste container with a lid [2]. The majority of the participants always kept all the garbage in one garbage container. The reason for the results is insufficient garbage container due to lack of knowledge for garbage management. These finding of the study is 
similar to the previous study conducted by [16]. The present study reveals that most of the participants always collect waste in a plastic bag. However, this result is not similar to the previous study conducted by [17]. The Study found that very few community people collected the waste in a plastic bag. The possible reasons for these differences are low economic status and not availability of plastic bags in the market.

\subsection{Relationship between Socio-Demographic Characteristics and Practice on Household Solid Waste Management among the Participants}

Household solid waste management training is important to improve the practice of community people. The current study showed that participants who received training on household solid waste management were significantly correlated with practice. The same result was found in a previous study conducted by [2]. This study showed that community people had not received any formal training on household solid waste management, because of the similar demographic background of respondents, waste management system, education, culture, and role of policy and living status. The current study also showed the relationship between types of solid waste and practice. This result is closely similar or consistent with the previous study conducted in India by [18]. The reason for similar results was that maximum solid wastes were unhygienic, unhealthier as well as sources of the different germ which affect human health and contaminated the environment.

However there is no relationship between awareness and practice regarding household solid waste management. This finding is dissimilar with the previous study conducted by [17]. Prior study showed the positive relationship between awareness and practice reason might be due to different education, background, better house hold solid waste management information system and positive practice environment. encourage the community people for practice of waste management in different way, such as provide training to the community people, increase the waste management information system, follow-up by local community leader, ensure dispose solid waste by waste collector and use lid with bin may be apply to improve the increase awareness and practice to make a positive relationship among the community people.

\section{Conclusion and Recommendations}

\subsection{Conclusion}

Overall awareness and practice level of household solid waste management was a moderate level in community people. Training on household solid waste management and recyclable waste were statistically significantly correlated with household solid waste management $\&$ practice. Policymakers can use this baseline data to make a strategy for increasing awareness among the community people. 


\subsection{Limitation of the Study}

One set, a small sample size, and a self-administered questionnaire were the main limitations of the study. The result of the current study cannot be generalized to other settings due to its unique characteristics. It may be more generalizable if data would be collected from a multiple setting.

\subsection{Recommendations}

Further study is needed by a large number of sample sizes and multiple settings on a large scale. An experimental study may be conducted to promote household solid waste management of the community people. An intervention study may be recommended to investigate the relationship between awareness and practice on household solid waste management. The current study findings would serve as baseline data for a higher authority to take steps for the initiative to increase awareness and practice level among the community people. Mass media can play a vital role in focusing on solid waste management for community people so that they can enhance their awareness level. A long-term awareness building, demonstrations through NGOs, and campaigning program may be organized to increase awareness and practice level of the community people. So therefore people will be motivated about waste segregation, recycling, reuse, cleanliness, and personal hygiene.

\section{Conflicts of Interest}

The authors declare no conflicts of interest regarding the publication of this paper.

\section{References}

[1] Sunarto, S., Bisri, M. and Suyadi, S. (2014) Society Behavior towards Household Waste Management in Tulungagung. International Journal of Applied Sociology, 4, 67-73.

[2] Adogu, P.O.U., Uwakwe, K.A., Egenti, N.B., Okwuoha, A.P. and Nkwocha, I.B. (2015) Assessment of Waste Management Practices among Residents of Owerri Munipal Imo State Nigeria. Journal of Environmental Protection, 6, 446.

https://www.scirp.org/html/4-6702622_56212.htm https://doi.org/10.4236/jep.2015.65043

[3] Islam, F.S. (2016) Solid Waste Management System in Dhaka City of Bangladesh. Journal of Modern Science and Technology, 4, 192-209. https://www.researchgate.net/profile/Fasamiul_Islam/publication/309790226_Solid _Waste_Management_System_in_Dhaka_City_of_Bangladesh/links/582393b108ae b45b58896084/Solid-Waste-Management-System-in-Dhaka-City-of-Bangladesh.pdf

[4] Shahzadi, A., Hussain, M., Afzal, M. and Gilani, S.A. (2018) Determination the Level of Knowledge, Attitude, and Practices Regarding Household Waste Disposal among People in Rural Community of Lahore. International Journal of Social Sciences and Management, 5, 219-224.

https://www.nepjol.info/index.php/IJSSM/article/view/20614

https://doi.org/10.3126/ijssm.v5i3.20614 
[5] Chengula, A., Lucas, B.K. and Mzula, A. (2015) Assessing the Awareness, Knowledge, Attitude and Practice of the Community towards Solid Waste Disposal and Ide tifying the Threats and Extent of Bacteria in the Solid Waste Disposal Sites in Morogoro Municipality in Tanzania. Journal of Biology, Agriculture and Healthcare, 5, 54-65.

https://www.researchgate.net/profile/Augustino_Chengula/publication/273256828_ As-

sessng_the_Awareness_Knowledge_Attitude_and_Practice_of_the_Community_to wards_Sold_Waste_Disposal_and_Identifying_the_Threats_and_Extent_of_Bacteri a_in_the_Solid_Waste_Disposal_Sites_in_Morogoro_M/links/54fc381d0cf20700c5e 965d3.pdf

[6] Hakami, B.A. and Seif, E.S.S.A. (2015) Household Solid Waste Composition and Management in Jeddah City, Saudi Arabia: A Planning Model. International Research Journal of Environment Sciences, 4, 1-10. http://www.isca.me/IJENS/Archive/v4/i1/1.ISCA-IRJEvS-2014-221.pdf

[7] Paghasian, M.C. (2017) Awareness and Practices on Solid Waste Management among College Students in Mindanao State University Maigo School of Arts and Trades. Proceedings of the 3 rd International Conference on Education and Training (ICET 2017), 128, 5-12.

https://www.atlantis-press.com/proceedings/icet-17/25883492 https://doi.org/10.2991/icet-17.2017.2

[8] Yasmin, S. and Rahman, M.I. (2017) A Review of Solid Waste Management Practice in Dhaka City, Bangladesh. International Journal of Environmental Protection and Policy, 5, 19-25. https://doi.org/10.11648/j.ijepp.20170502.11

[9] Sarker, B.C., Sarker, S.K., Islam, M.S. and Sharmin, S. (2012) Public Awareness about Disposal of Solid Waste and Its Impact: A Study in Tangail Pourashava, Tangail. Journal of Environmental Science and Natural Resources, 5, 239-244.

https://www.banglajol.info/index.php/JESNR/article/view/14821 https://doi.org/10.3329/jesnr.v5i2.14821

[10] Afroz, R., Masud, M.M., Akhtar, R. and Duasa, J.B. (2013) Survey and Analysis of Public Knowledge, Awareness and Willingness to Pay in Kuala Lumpur, Malaysia-A Case Study on Household WEEE Management. Journal of Cleaner Production, 52, 185-193.

https://www.sciencedirect.com/science/article/pii/S095965261300053X https://doi.org/10.1016/j.jclepro.2013.02.004

[11] Desa, A., Kadir, N.B.A. and Yusooff, F. (2011) A Study on the Knowledge, Attitudes, Awareness Status and Behaviour Concerning Solid Waste Management. Procedia-Social and Behavioral Sciences, 18, 643-648.

https://www.sciencedirect.com/science/article/pii/S1877042811012080 https://doi.org/10.1016/j.sbspro.2011.05.095

[12] Licy, C.D., Vivek, R., Saritha, K., Anies, T.K. and Josphina, C.T. (2013) Awareness, Attitude and Practice of School Students towards Household Waste Management. Journal of Environment, 2, 147-150

https://www.researchgate.net/profile/Vivek_Raghavan2/publication/269520226_Aw areess_Attitude_and_Practice_of_School_Students_towards_Household_Waste_Ma nagement/links/548e6d9e0cf2d1800d8424ba.pdf

[13] Zakianis, S. and Djaja, I.M. (2017) The Mnimportance of Waste Management Knowledge to Encourage Household Waste-Sorting Behaviour in Indonesia. International Journal of Waste Resources, 7, 4.

https://www.longdom.org/open-access/the-importance-of-waste-management-kno 
wledge-to-encourage-householdwastesorting-behaviour-in-indonesia-2252-5211-10 00309.pdf

[14] Almasi, A., Mohammadi, M., Azizi, A., Berizi, Z., Shamsi, K., Shahbazi, A. and Mosavi, S.A. (2019) Assessing the Knowledge, Attitude and Practice of the Kermanshahi Women towards Reducing, Recycling and Reusing of Municipal Solid Waste. Resources, Conservation and Recycling, 141, 329-338.

https://www.sciencedirect.com/science/article/abs/pii/S0921344918303823 https://doi.org/10.1016/j.resconrec.2018.10.017

[15] STREET, K. (2014) Community Participation in Solid Waste Management at Guluka (Doctoral Dissertation, The Open University).

http://repository.out.ac.tz/760/

[16] Yoada, R.M., Chirawurah, D. and Adongo, P.B. (2014) Domestic Waste Disposal Practice and Perceptions of Private Sector Waste Management in Urban Accra. BMC Public Health, 14, 697.

https://bmcpublichealth.biomedcentral.com/articles/10.1186/1471-2458-14-697 https://doi.org/10.1186/1471-2458-14-697

[17] Alemayehu, D.S., Regasa, M.S., Mengestie, B. and Alemayehu, T. (2017) Household Solid Waste Management Practice Associated Factors and Service Delivery Performance of Private Solid Waste Collectors in Dire Dawa City, Eastern Ethiopia. In ternational Journal of Innovative Research in Science, Engineering and Technology, 6, 1-12.

https://www.semanticscholar.org/paper/Household-Solid-Waste-Management-Prac ice-Factors-Alemayehu-Regasa/45d4a311d595d345821f263d531f1d350da83586

[18] Sharma, K.D. and Jain, S. (2020) Municipal Solid Waste Generation, Composition, and Management: The Global Scenario. Social Responsibility Journal, 16, 917-948. https://www.emerald.com/insight/content/doi/10.1108/SRJ-06-2019-0210/full/html https://doi.org/10.1108/SRJ-06-2019-0210 


\section{Appendix 1. Data Collection Questionaire (English)}

ID

Direction: Each participant will be answer following question through face to face interview and the investigator mark " $\sqrt{ }$ " or write in the appropriate section.

Ward No------

Date---

\begin{tabular}{|c|c|c|c|}
\hline \multicolumn{4}{|c|}{ Section A: Personal information } \\
\hline \multicolumn{2}{|l|}{ SL No } & \multicolumn{2}{|l|}{ Particulars } \\
\hline 1 & Age & . & years. \\
\hline 2 & Gender & a) Male & b) Female \\
\hline \multirow{2}{*}{3} & \multirow{2}{*}{ Religion } & a) Islam & b) Hindu \\
\hline & & c) Christian & d) Buddhist \\
\hline \multirow{2}{*}{4} & \multirow{2}{*}{ Marital status } & a) Married & b) Unmarried \\
\hline & & c) Widowed & d) Divorced \\
\hline \multirow{3}{*}{5} & \multirow{3}{*}{ Occupation } & a) Govt job & b) Private job \\
\hline & & c) House wife & d) Business \\
\hline & & e) Self service & f) Other \\
\hline \multirow{3}{*}{6} & \multirow{3}{*}{ Education } & a) No education & b) Primary \\
\hline & & c) Secondary & d) H S C \\
\hline & & \multicolumn{2}{|l|}{ e) More than HSC } \\
\hline 7 & Monthly family income & (n............... & ..BD Taka. \\
\hline 8 & Residential status & a) Own & ted \\
\hline 9 & Types of Solid Waste & $\begin{array}{l}\text { a) Recyclable was } \\
\text { b) Non Recyclabl } \\
\text { c) Others }\end{array}$ & \\
\hline 10 & $\begin{array}{l}\text { Problem in household solid waste } \\
\text { management } \\
\text { (Check all that apply) }\end{array}$ & $\begin{array}{l}\text { There is no good } \\
\text { b) Cost is high } \\
\text { c) Irregular Servi } \\
\text { d) Lack of Conta } \\
\text { e) Others }\end{array}$ & $\begin{array}{l}\text { for disposal of waste. } \\
\text { collect waste at home }\end{array}$ \\
\hline 11 & $\begin{array}{l}\text { Have you any training on household } \\
\text { solid waste management? }\end{array}$ & $\begin{array}{l}\text { a) Yes } \\
\text { b) No }\end{array}$ & \\
\hline
\end{tabular}


Part-2: Awareness on Household Solid Waste Management related Question.

Direction: This part is designed to assessed the level of awareness regarding household solid waste management, please tick " $\sqrt{ }$ " mark on the appropriate box whether your answer is Yes/No/Don't Know

$1=$ Yes, 2 = No, 3 = Don't know

SL. No.

Item-12

1 Household solid waste management committee are needed in the community.

2 Every people have to know about household solid waste management.

3 Local authorities have no role to play in the house hold solid waste management.

4 Respiratory distress, diarrhea and many other diseases arise due to improper waste management.

$5 \quad$ Household solid waste can't reuse or recycle.

6 Everybody awarded of electronic household solid waste management.

7 Waste disposal on open places will be harmful for human health.

8 Community people are awarded of any legislation which governs household solid waste management.

$9 \quad$ All streets should be clean and free of waste.

10 Incineration is the effective disposal mechanism for household solid waste management.

11 Delay in household solid waste disposal causes of many difficulties.

12

I am always concern about collect and dispose of household solid waste management. 
Part-3: Practice on Household Solid Waste Management related Question.

Direction: This part is designed to assessed for practice regarding household solid waste management, please tick " $\sqrt{ }$ " mark on the appropriate box whether your answer is Never/Seldom/Sometimes/Often/Always

Item-14

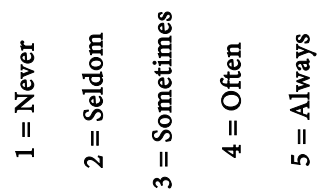

1 I use different bins for waste disposal.

2 I throw waste to drain.

3 I use our kitchen waste as compost to me for gardening.

4 I reuse grocery bags.

5 I reuse our old materials than buying a new one.

6 I throw waste to open dump.

$7 \quad$ I throw waste to open field.

8 I collect the waste in a household container without cover.

9 I collect the waste in plastic bag.

I segregate biodegradable (paper, banana peels, cardboard

10 and vegetables) and non biodegradable (plastic toys, glass steel, rubber) wastes at home.

11 I keep all the garbage in one garbage container.

I use to burn the solid waste when I have bulk amount of solid waste.

13 I dispose the solid waste regularly.

14 I dispose solid waste to waste collector.

\section{Thank you very much for your kind cooperation \& participation}

